\section{HYPERPYREXIA AND ANAESTHESIA}

BY

\author{
R. CECIL BROWN, M.D., F.F.A. R.C.S. \\ Assistant Anaesthetist, Western Infirmary, Glasgow
}

A recent fatality associated with anaesthesia displayed such remarkable features that it was thought useful to publish a short account of it.

\section{Case Report}

The patient, a girl of 13 , was subjected to operation for recurrent dislocation of the patella. No abnormality was found on physical examination. Premedication consisted of morphıne, $\frac{1}{8}$ gr. $(8 \mathrm{mg}$.), and atropine, $1 / 100 \mathrm{gr}$. (0.65 mg.), given, as it happened, two hours before induction of anaesthesia. In the anaesthetic room the patient was perhaps (in retrospect) a little flushed, but seemed otherwise normal. Anaesthesia was induced smoothly with $0.4 \mathrm{~g}$. sodium thiopentone, and continued with $\mathrm{N}_{2} \mathrm{O}$ ( 5 litres a minute), $\mathrm{O}_{2}$ (1.5 litres a minute), and minimal trichlorethylene (" trilene "), using Boyle's semiclosed circuit. A tourniquet was applied to the affected leg and the patient was taken into the theatre. It is regrettable, in view of what ensued, that no detailed records were made of pulse rate, blood pressure, etc., but this was regarded as a minor routine case.

The only complication observed in the course of forty minutes' anaesthesia was laryngeal "crowing," which was not affected by giving an $\mathrm{O}_{2}$ and $\mathrm{CO}_{2}$ mixture. It was not, however, regarded seriously, as the volume of respiratory exchange was adequate and the patient's colour was pink.

After forty minutes' anaesthesia, respiratory exchange suddenly decreased in volume. At the same time, clonic convulsive movements were observed in the arms and the abdominal muscles. Respiration stopped and some cyanosis occurred. Anaesthetic administration was stopped, oxygen was given by forced inflation, and the head was raised. In about thirty seconds the movements stopped, respiration of full volume was restored, and the colour once more became pink. It was then noticed that the patient's skin was very hot. The axillary temperature was taken and found to be $108.6^{\circ} \mathrm{F}$. $\left(42.6^{\circ} \mathrm{C}\right.$.). A second thermometer was sent for ; the temperature was taken again, and found to be $110^{\circ} \mathrm{F}$. $\left(43.3^{\circ}\right.$ C.). Anaesthesia was discontinued, though $\mathrm{O}_{2}$ was still given. The theatre temperature was $79^{\circ} \mathrm{F} .\left(26.1^{\circ} \mathrm{C}\right.$. $)$.

The patient was removed to an adjoining room and stripped; the windows were opened; and sponging was started with ice-water, particularly over the groins, neck, axillae, and praecordium. About twenty-five minutes after the first untoward signs were noted the temperature had fallen to $104^{\circ} \mathrm{F}$. $\left(40^{\circ} \mathrm{C}\right.$.). After another fifteen minutes it had fallen to $102^{\circ} \mathrm{F}$. $\left(38.9^{\circ} \mathrm{C}\right.$.). The pulse rate had now risen to about 200 a minute. Some signs of spasticity appeared in the limbs, but there was no return of consciousness. Peripheral circulation returned very slowly to the affected leg after removal of the tourniquet. The patient was returned to bed, covered by a sheet, the head was kept raised, $\mathrm{O}_{2}$ was administered, and a glucose-saline drip was started. When the patient was seen a little later by a neurosurgeon he considered that she showed signs of a brain-stem lesion. About seven hours after the first untoward signs were noted the patient died.

At necropsy the body showed marked cyanosis. The operation site presented no unusual features. The upper respiratory tract was healthy. The tonsils were enlarged, and the lymphoid tissue at the base of the tongue was hypertrophied. The thymus was prominent, the lungs were congested, and the heart was normal.

On opening the skull the dura was seen to be a little tense, and the cerebral hemispheres were slightly dry and a little flattened, suggesting increased cerebral pressure. This was confirmed by a small cerebellar pressure cone. The brain was deeply congested and markedly oedematous, but no abnormality was found on careful dissection of the cerebral blood vessels. No other abnormalities were found in the brain, brain stem, or spinal cord.

The pathologist concluded that death was due to comatoasphyxia following anaesthesia.

\section{Investigations}

Although it was thought unlikely that there was any connexion between the occurrence and the actual trichlorethylene used, it was suggested that a sample should be analysed. Unfortunately, none from the same tin was available, but a tin of the same batch was taken from stock, analysed, and found to be in complete conformity with B.P. standards.

This distressing case led to some routine observations of axillary temperature changes in patients before and during anaesthesia. One child was found to have a temperature of $101.4^{\circ} \mathrm{F} .\left(38.6^{\circ} \mathrm{C}.\right)$ in the theatre. Another child had a temperature of $100.5^{\circ} \mathrm{F}$. $\left(38^{\circ} \mathrm{C}\right.$. $)$. This led to some consideration of environmental factors.

The theatre concerned is air-conditioned. The anteroom (A in Diagram) in which patients lie until they are anaes-

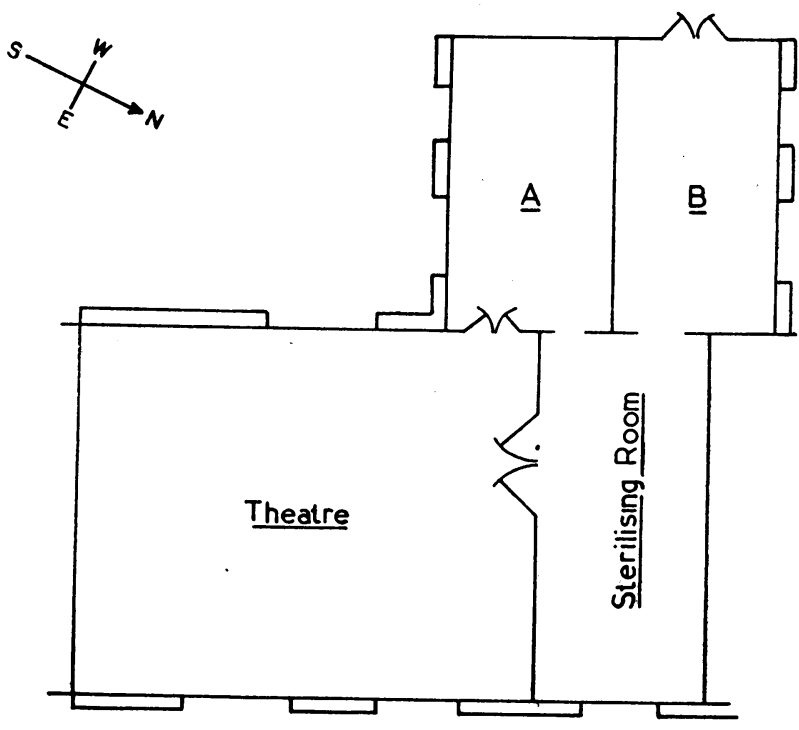

Plan of part of the theatre suite.

thetized is not air-conditioned. This room has large windows, and is so positioned that the sun, when unobscured shines directly into it all morning. There is a corresponding anteroom, B, adjacent to $\mathrm{A}$, which is not exposed in this fashion to the sun. Records were kept by wall thermometers of the temperature changes in the three rooms on ten days in the months of June-September, 1954. A record was also made of the wet-bulb temperature, using a whirling psychrometer. (According to Clark et al., 1954, the wetbulb temperature is the best measure of thermal tolerability. They claim that heat retention is unlikely in adults if the wet-bulb temperature is under $75^{\circ} \mathrm{F} .-23.9^{\circ} \mathrm{C}$.)

The theatre temperature varied from 73 to $80^{\circ} \mathrm{F}$. $(22.8$ to $26.7^{\circ} \mathrm{C}$.). On an isolated occasion it rose to $83.5^{\circ} \mathrm{F}$. $\left(28.6^{\circ} \mathrm{C}\right.$.) for a brief period. The wet-bulb temperature did not exceed $66^{\circ} \mathrm{F}$. $\left(18.9^{\circ} \mathrm{C}\right.$.) on any occasion on which it was measured. The temperature in room $\mathbf{A}$ varied from 79 to $85^{\circ} \mathrm{F}$. $\left(26.1\right.$ to $29.5^{\circ} \mathrm{C}$.). The wet-bulb temperature did not exceed $69^{\circ} \mathrm{F} .\left(20.6^{\circ} \mathrm{C}\right.$. $)$. In room B the temperature varied from 73 to $79.5^{\circ} \mathrm{F}$. $\left(22.8\right.$ to $26.4^{\circ} \mathrm{C}$.), with a maximum wet-bulb temperature of $66^{\circ} \mathrm{F}$. $\left(18.9^{\circ} \mathrm{C}\right.$. $)$. 
Observations were not possible in conditions approximating to those of the day of the fatality until late in September. This was a rather cool morning, but there was brilliant sunshine. Radiators were not in use. At 1.30 p.m. the shade temperature in room $\mathrm{A}$ was $85^{\circ} \mathrm{F}$. $\left(29.5^{\circ} \mathrm{C}\right.$.) (the sun temperature was $95^{\circ}$ F. $-35^{\circ}$ C.). The wet-bulb temperature was $69^{\circ} \mathrm{F}$. $\left(20.6^{\circ} \mathrm{C}\right.$.). In room B the shade temperature was $79.5^{\circ} \mathrm{F}$. $\left(26.4^{\circ}\right.$ C.) and the wet-bulb temperature was $66^{\circ}$ F. $\left(18.9^{\circ}\right.$ C. $)$. In the theatre the shade temperature was $79^{\circ} \mathrm{F} .\left(26.1^{\circ} \mathrm{C}\right.$.), the wet-bulb temperature was $66^{\circ}$ F. $\left(18.9^{\circ}\right.$ C.) and the temperature under the mackintosh sheet which covered the patient was $91.5^{\circ} \mathrm{F}$ (33.1 ${ }^{\circ}$ C.). (On another day, when the theatre temperature was $73^{\circ} \mathrm{F}$. $\left(22.8^{\circ} \mathrm{C}\right.$.), the temperature under a mackintosh sheet covering a patient was $87^{\circ}$ F. $-30.6^{\circ}$ C.)

No other marked rises in axillary temperature were found, but a slight rise of the order of $0.5-1^{\circ} \mathrm{F}$. $\left(0.3-0.6^{\circ} \mathrm{C}\right.$.) was frequently observed in young patients confined in room $A$ on sunny days. The deceased had lain in room $\mathbf{A}$ for one and a half hours at the hottest part of the day. This was most unusual, and was due to an unexpected prolongation of the preceding operation.

\section{Discussion}

The most striking feature of this case is the extreme hyperpyrexia. It is difficult to believe that the very brief convulsive episode was responsible for a rise of temperature to $110^{\circ} \mathrm{F}$. $\left(43.3^{\circ} \mathrm{C}\right.$.). Even after lengthy and severe convulsions in a 12-year-old boy, Wright (1933) records a temperature of only $106.8^{\circ} \mathrm{F}$. $\left(41.6^{\circ} \mathrm{C}\right.$.) -the temperature at the beginning of the operation being $101^{\circ} \mathrm{F}$. (38.3 $\left.3^{\circ} \mathrm{C}.\right)$. Convulsions have been reported in association with trichlorethylene anaesthesia by Culbert (1942), by Garland (1942), and by Condon (1948). In each of those cases the patient's temperature was normal both before and after the convulsions.

While it is unlikely that the wet-bulb temperatures exceeded the limits of thermal tolerability for an adult on the day of the fatality, they may have done so for a patient such as this 13-year-old girl. It is probable that her temperature started to rise in room $A$, and continued to rise in the theatre, when partly covered by a mackintosh sheet and wholly covered by drapes. It is perhaps worth considering whether this, in a convulsion-prone individual, would initiate convulsions, which would cause further pyrexia. It is perhaps worth emphasizing that when a patient is covered by a mackintosh sheet the temperature under the sheet may exceed the theatre temperature very considerably.

The subject of hyperpyrexia in the post-operative period has been ably reviewed by Mangiardi (1951), who claims that patients can survive a temperature of over $108^{\circ} \mathrm{F}$. $\left(42.2^{\circ}\right.$ C.) with full recovery.

\section{Summary}

A fatality associated with the anaesthesia of an apparently fit girl of 13 is recorded. The outstanding features were a brief convulsive episode and a hyperpyrexia of $110^{\circ} \mathrm{F}$. $\left(43.3^{\circ} \mathrm{C}\right.$.). No lesion which might account for this was found in the brain at necropsy. Some environmental factors that may be significant are reported.

I am indebted to Dr. H. H. Pinkerton for advice, to Dr. H. E. Hutchison for the necropsy report, to May and Baker Ltd. for help with references, and to Imperial Chemicals (Pharmaceuticals) Ltd. for the analysis of trilene.

\section{REFERENCES}

Clark, R. E., Orkin, L. R., and Rovenstine, E. A. (1954). J. Amer. med. Ass., 154, 311 .

Condon, H. A. (1948), British Medical Journal, 2, 340

Culbert, T. D. (1942). Ibid., 2, 679.

Garland, Y. (1942). Ibid., 2, 607.

Mangiardi, J. L. (1951). Amer. J. Surg., 81, 189.

Wright, A. D. (1933). British Medical Journal, 2, 1210

\section{PRURITUS IN MELANCHOLIA}

BY

\author{
KENNETH C. S. EDWARDS, M.R.C.S., D.P.M. \\ Late Assistant Psychiatrist, North Wales Mental Hospital, \\ Denbigh
}

Emotional states have long been recognized as causative agents in some skin reactions. The literature contains many references to the psychological factors found in sufferers from skin complaints. MacKenna (1944) had correlated particular skin reactions with different personality types. Hellier (1944) has drawn attention to environmental and psychological influences in skin conditions. He states : "He [the eczema patient] may adjust himself to the environment, but the rash is likely to return at puberty, at the menopause, or old age, or at any other time when things go against him." Hall-Smith and Norton (1952), in a psychiatric survey of a random sample of skin out-patients, found psychological factors in $78.5 \%$ of their patients. Of these, the largest group contained those of the anxious-obsessional type. There were no psychotics in their series, and they remarked that the symptoms characteristic of endogenous varieties of depression were conspicuously absent.

That a relationship exists between psychological factors and skin reactions appears to be generally accepted. In most cases reported in the literature the patients were clearly considered to be showing a neurotic reaction, and little mention is made of psychosis. Shorvon, Rook, and Wilkinson (1950), in reporting on the treatment of 50 cases of dermatitis by abreactive techniques, mentioned that one of the cases was psychotic and failed to respond to treatment. On the other hand, Forman (1954), in a review of cases of pruritus, found that in 23 of his 62 cases psychological factors appeared to be causative, and of those 23 cases it seems likely, from the diagnosis made, that four were psychotic.

It is, however, generally less appreciated that pruritus and skin reactions may be due to melancholia, and the following cases are of interest in that respect.

\section{Case 1}

A spinster of 55 years was seen in the wards of a general hospital nine days after she made a suicidal attempt by taking $66 \frac{1}{2}$-gr. (32-mg.) tablets of phenobarbitone. At that time she was agitated and depressed, expressing marked ideas of hopelessness. Her skin condition was poor. She had a weeping dermatitis of both arms, shoulders, breasts, and buttocks which she managed to scratch despite the covering bandages.

Her history showed that the dermatitis had started in 1946 and had not responded to any form of treatment. She had also suffered from poor, disturbed sleep and loss of appetite over the previous three to four years. These symptoms had been attributed to the dermatitis and pruritus. More recent symptoms were loss of taste and smell.

She was admitted to the reception unit of the North Wales Mental Hospital in May, 1952, when the diagnosis of endogenous depression was made. Her skin condition, with the intense pruritus and weeping dermatitis, was considered to be secondary to her mental state and was treated conservatively with bland ointments only. In view of the risk of another suicidal attempt, electric convulsion therapy (E.C.T.) was started without delay.

The initial response to treatment was good, both her depression and her dermatitis largely clearing up. A month after admission, however, the agitation and depression 